rules that help support this foundation ultimately pose staunch contradictions when it comes to rights attainment. While Biddulph's monograph is comprehensive in its explication of the unique circumstances in contemporary China, this book would benefit from more theoretical engagements regarding the shift from Maoist and Marxist influences to the current Communist state. Furthermore, discussions about the dialectics between rights and rules could be strengthened by more analysis of the use of discipline and punish as constantly shifting sources of power that intersect with the structures of economics and politics. Overall, however, this is a thoughtfully researched and organized text that engages with the complexities of the desires for valuing human rights and the contradictory needs for control of dissent vis-à-vis larger global human rights landscapes.

Yvonne KWAN

Dartmouth College

Celeste L. Arrington, Accidental Activists: Victim Movements and Government

Accountability in Japan and South Korea (Ithaca: Cornell University Press, 2016) pp 234. Hardcover: \$39.95.

doi:10.1017/als.2016.63

First published online 23 January 2017

Civil protest and litigation are well-established mechanisms for social change in the US and other "Western" liberal democracies. In the Republic of Korea (Korea) and Japan, these efforts are typically seen as less sustained with fewer consequential results. Celeste L. Arrington, in Accidental Activists, revises that picture with a comparative study of cases where civil groups in both countries sometimes achieved responsive official inquiries, apologies, compensation, and reforms. This is a rare and important work, challenging conventional wisdom.

Arrington reveals three institutions that primarily contributed to the movements' successes and failures: diversity of the news media, autonomy of the legal profession, and politicization of the activist sector. More politically diverse media, which exist in Korea, create low barriers for civil groups but limit the readership for a given story. Japan's media are more homogeneous, which means fewer access points, but, once a cause gains the media's attention, its message becomes ubiquitous. Korea's politically connected legal community provides elite access for victim groups, but Japan's more autonomous legal establishment, with a less politicized history of "cause lawyering," is better at building grassroots movements. Korea's well-established activist sector can influence policy-making, but it encourages Koreans to frame social issues in political terms to build a coalition of activist groups and appeal to politicians. The politicization of Korea's media, lawyers, and civil society is an artefact of the 1980s democracy movement against the country's authoritarian government. Japan's postwar activism has, instead, grown from small, local self-help organizations, focusing on narrow issues and allowing for a less politicized and thus broad-based movement.

Arrington's most interesting and counterintuitive revelation for both academics and civic groups is that early elite support retards the type of grassroots movement that can sustain 
pressure on governments for fuller redress. Elite support does not inherently undermine social movements; rather, the sequence of elite support matters.

She tests her model across three victim movements occurring contemporaneously in Korea and Japan: victims of Hansen's disease (Leprosy), Hepatitis C (HCV)-contaminated blood products, and North Korean abductions. Success varied because of the distinct interactions among individuals (movement leaders, lawyers, and experts) and institutions (courts, media, and government) in determining social and government responsiveness. Each case offers its own lessons and reveals something about the dynamics of social change in these two relatively new liberal democracies that continue to carry the vestiges of their autocratic, development state histories.

Hansen victims were treated brutally by the Japanese and Korean governments through most of the twentieth century, including forced sterilization, abortions, and segregation, with discrimination continuing after those extreme policies ended. Victims' claims accelerated during the 1990s in Japan and later in Korea. Because Japanese elites did not provide early support, Hansen survivors mobilized at the grassroots and obtained fuller redress than their Korean counterparts who found elite backers earlier. Korean HCV victims obtained early elite support and relied on the established haemophiliac organization, impeding a grassroots movement. Redress for victims of North Korean abductions and their families was partial in both countries because of early elite assistance, even with subsequent grassroots mobilizations.

Left unclear is whether the Korean cases can be partially explained by the public's negative attitude toward political elites. Low trust in political leaders is also an artefact of the authoritarian era and the result of recent governance failures. Low transparency in decisionmaking triggered large protests against the decision to lift a ban on US beef imports (2008) and share military intelligence with Japan (2012). Regulatory failures were tied to the 2014 Sewol ferry sinking, killing 304 persons, mostly Korean adolescents. Several corruption scandals have further undermined trust, including the ongoing controversy over President Park Guen-hye's relationship with Choi Soon-sil, who is accused of trading on her presidential influence. Perhaps, victim movements in Korea underperformed because elite allies were not able to lead on the issue, regardless of the sequencing of their support.

Also unclear is why courts, which often are an integral part of the victims' success, are not "elite" allies that similarly deter grassroots mobilization and undermine public sympathy. Particularly in Japan, the courts seem to work synergistically with civil society, media, and political elites to achieve redress and public consensus supporting victim groups. However, in the US (which is not covered in Arrington's book), abortion rights and same-sex marriage movements have not achieved comprehensive legislative victories or political/social consensus, in part because the process was interrupted by Supreme Court victories. Perhaps, then, Arrington has unintentionally exposed the problematic role of elites at any stage of social movements. Though the abortion rights and same-sex marriage movements in the US built strong grassroots organizations prior to their Supreme Court victories, the Court's intervention left in place strong, oppositional movements, particularly with abortion. This same scenario may be unfolding in the US over the issue of transgender access to single-sex facilities like restrooms and dressing rooms. Thus, a related research question is whether elites, even operating with a strong grassroots movement, can interrupt the development of a social consensus on a contentious civil rights issue.

For those in North-East Asia, Arrington's book has special meaning. Her inductions about the dynamics of successful victim movements may have broad application, but her case-study on Hansen victims offers a specific template for Korea and Japan (and China) to find 
common ground in solving the historical issues that continue to roil this region. The process that led the Japanese government to compensate Koreans living in Japan and Korea, along with the support Japanese lawyers provided victims in Korea, is one path for resolving remaining controversies, including forced labour during Japan's colonization of Korea, Japanese textbooks' descriptions of that colonial history, and the treatment of Koreans now living in Japan.

Joe PHILLIPS

Pusan National University

\section{Shahla F. Ali. Governing Disasters: Engaging Local Populations in Humanitarian Relief (New York: Cambridge University Press, 2017) pp 346. Paperback: \$32.00. doi:10.1017/als.2017.17}

First published online 5 September 2017

The highlight of this masterpiece by Dr Shahla F. Ali, Associate Professor on the Faculty of Law at the University of Hong Kong, is her comparative investigation into various forms of "constellation" between international, state, and local institutions in recent mega-disasters around the world. She applies a grand perspective, ranging from the developing countries highly dependent on international humanitarian aid, such as Indonesia (2004 Aceh Tsunami), Haiti (2010 Haitian Earthquake), and Myanmar (2008 Cyclone Nargis), to advanced economies that generally conduct disaster relief independently from international intervention, such as Japan (2011 East Japan Earthquake and Tsunami) and the US (2005 Hurricane Katrina). Throughout the thick volume, consisting of 13 chapters, the author maintains her fundamental concern - the building of local institutional capacity for better co-ordination in a timely and effective manner with international humanitarian support in the disaster emergency phases.

The methodological approach here is mainly a "meta-analysis": she intensively reviewed many publicly accessible articles that were written about the emergency phase operations of the mega-disasters which she covered. In this sense, her main source of information is an abundance of secondary information, instead of her own surveys, except the questionnaire survey conducted with 69 humanitarian aid practitioners for the purpose of supporting the findings from the proceeding "meta-analysis," which is summarized in Chapter 12. This basic dependency on secondary information is, however, not at all a weakness of this volume. To the contrary, this is the true contribution of this work, since a "meta-analysis" has been longawaited and highly necessary in the field of disaster management. Particularly in relation to emergency phases, most of the "academic" writings tend to be temporary reports containing the subjective observations of authors. Only a thorough review from chronological and comparative perspectives can yield true lessons from the phenomena of disaster operations.

In this significant attempt at "meta-analysis," the author has successfully identified a number of valuable lessons. One remarkable suggestion is the necessity for leading international institutions to pay more attention to the importance of constructing a trusting relationship with existing local institutions, not only public administration, but also local communities, so as to better access existing local knowledge and resources. In this sense, 